\title{
Bruk av elektrokonvulsiv terapi
}

\begin{abstract}
Det er store variasjoner i utbredelse og praksis ved bruk av elektrokonvulsiv terapi i Norge, men også i resten av verden, til tross for internasjonale retningslinjer.
\end{abstract}

Elektrokonvulsiv terapi (ECT) er en effektiv og veldokumentert behandlingsmetode for alvorlige depresjoner, men også for andre psykiske lidelser som mani og noen former for schizofreni. Ved elektrokonvulsiv terapi utløses et epileptisk anfall ved hjelp av elektrisitet. Behandlingen utføres under narkose og muskelrelakserende medikamenter. Litteratur tyder på at det er stor variasjon både når det gjelder utbredelse og praksis ved bruk av elektrokonvulsiv terapi innad i sykehus, mellom regioner og mellom land.

I min doktorgradsavhandling kartlegges bl.a. utbredelse av elektrokonvulsiv terapi, diagnoser, alder, kjønn og praktisk gjennomføring av elektrokonvulsiv terapi samt holdninger, fortrinnsvis i Norge, men også globalt.

I Norge var det 2,4 per 10000 innbyggere ( $\geq 18$ år) per år som fikk elektrokonvulsiv terapi i 2004, med en variasjon fra 1,83 i Helse Nord til 3,44 i Helse Vest. Ingen under 18 år fikk elektrokonvulsiv terapi. Internasjonalt varierte bruken av elektrokonvulsiv terapi fra 0,11 til 5,1. Det var flest eldre kvinner med depresjon som fikk terapien i vestlige land, mens yngre menn med schizofreni dominerte i asiatiske og afrikanske land. Norske psykiatere uttrykte positive holdninger til elektrokonvulsiv terapi, og de rapporterte god effekt med milde og forbigående bivirkninger. Elektrokonvulsiv terapi uten narkose ble brukt i Asia, Afrika, Latin-Amerika, Russland, Tyrkia og Spania.

Funnene viser store internasjonale forskjeller, og det er et klart behov for fortsatt å dele kunnskap om elektrokonvulsiv terapi, bedre opplæring av helsepersonell og bedre dokumentasjon, f.eks. gjennom et nasjonalt register og retningslinjer.

Lindy Jarosch-von Schweder lindy.jarosch@ntnu.no

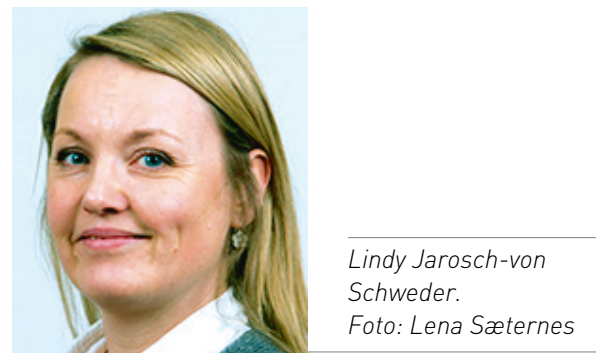

Disputas

Lindy Jarosch-von Schweder disputerte for ph.d.-graden ved Norges teknisk-naturvitenskapelige universitet (NTNU) 22.1.2015. Tittelen på avhandlingen er Use of electroconvulsive therapy in psychiatry.

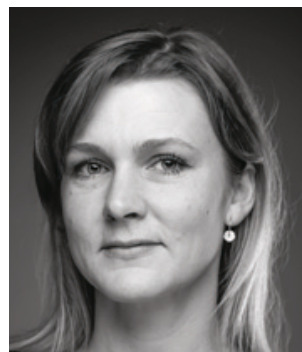

Synne Jenum at genet $R A B 33 A$ kan brukes til å identifisere barn med tuberkulose, eventuelt i kombinasjon med andre gener (areal under kurven, AUC: 0,78-0,92). T-celler med evne til koproduksjon av flere cytokiner har vært antatt å beskytte mot utvikling av tuberkulose i smittede personer. Vi fant imidlertid et lavere antall av disse cellene i friske ungdommer som bekjempet M.tuberculosis etter smitte.

Arbeidet bidrar til økt kunnskap om diagnostiske og prediktive tuberkulosemarkører hos barn, som er et satsingsfelt definert av Verdens helseorganisasjon.

\section{Synne Jenum}

Synne.jenum@rr-research.no
Foto: Kristin Ellefsen

Disputas

Synne Jenum disputerte for ph.d.-graden ved Universitetet i Oslo 8.12.2014. Tittelen på avhandlingen er Mycobacterium tuberculosis infection and disease - a contribution to the understanding of immunological diagnostics in children. under tre år (henholdsvis $31 \%$ og $23 \%$ ). Korrigert for andre faktorer var alder under to år assosiert med negative tuberkulintester og inkonklusiv Quantiferon-test. Sannsynligheten for inkonklusiv Quantiferon-test økte også ved interkurrent sykdom (hoste og feber) 